\title{
Genome-wide high-throughput signal peptide screening via plasmid pUC256E improves protease secretion in Lactiplantibacillus plantarum and Pediococcus acidilactici
}

Binbin Chen ${ }^{1}$, Bryan Zong Lin Loo ${ }^{1}$, Ying Ying Cheng ${ }^{1}$, Peng Song ${ }^{2}$, Huan Fan ${ }^{1,3}$, Oleg Latypov ${ }^{1 *}$ and Sandra Kittelmann ${ }^{1 *}$

\begin{abstract}
Background: Proteases catalyze the hydrolysis of peptide bonds of proteins, thereby improving dietary protein digestibility, nutrient availability, as well as flavor and texture of fermented food and feed products. The lactobacilli Lactiplantibacillus plantarum (formerly Lactobacillus plantarum) and Pediococcus acidilactici are widely used in food and feed fermentations due to their broad metabolic capabilities and safe use. However, extracellular protease activity in these two species is low. Here, we optimized protease expression and secretion in L. plantarum and P. acidilactici via a genetic engineering strategy.

Results: To this end, we first developed a versatile and stable plasmid, pUC256E, which can propagate in both L. plantarum and P. acidilactici. We then confirmed expression and secretion of protease PepG1 as a functional enzyme in both strains with the aid of the previously described L. plantarum-derived signal peptide LP_0373. To further increase secretion of PepG1, we carried out a genome-wide experimental screening of signal peptide functionality. A total of 155 predicted signal peptides originating from L. plantarum and 110 predicted signal peptides from P. acidilactici were expressed and screened for extracellular proteolytic activity in the two different strains, respectively. We identified 12 L. plantarum signal peptides and eight P. acidilactici signal peptides that resulted in improved yield of secreted PepG1. No significant correlation was found between signal peptide sequence properties and its performance with PepG1.

Conclusion: The vector developed here provides a powerful tool for rapid experimental screening of signal peptides in both L. plantarum and P. acidilactici. Moreover, the set of novel signal peptides identified was widely distributed across strains of the same species and even across some closely related species. This indicates their potential applicability also for the secretion of other proteins of interest in other L. plantarum or P. acidilactici host strains. Our findings
\end{abstract}

*Correspondence: oleg.latypov@sg.wilmar-intl.com; sandra.

kittelmann@sg.wilmar-intl.com

${ }^{1}$ Wilmar International Limited, WIL@NUS Corporate Laboratory, Centre

for Translational Medicine, National University of Singapore, Singapore,

Singapore

Full list of author information is available at the end of the article

(c) The Author(s) 2022. Open Access This article is licensed under a Creative Commons Attribution 4.0 International License, which permits use, sharing, adaptation, distribution and reproduction in any medium or format, as long as you give appropriate credit to the original author(s) and the source, provide a link to the Creative Commons licence, and indicate if changes were made. The images or other third party material in this article are included in the article's Creative Commons licence, unless indicated otherwise in a credit line to the material. If material is not included in the article's Creative Commons licence and your intended use is not permitted by statutory regulation or exceeds the permitted use, you will need to obtain permission directly from the copyright holder. To view a copy of this licence, visit http://creativecommons.org/licenses/by/4.0/. The Creative Commons Public Domain Dedication waiver (http://creativeco mmons.org/publicdomain/zero/1.0/) applies to the data made available in this article, unless otherwise stated in a credit line to the data. 
demonstrate that screening a library of homologous signal peptides is an attractive strategy to identify the optimal signal peptide for the target protein, resulting in improved protein export.

Keywords: Signal peptide, Protease secretion, High-throughput screening, Genetic engineering, Lactiplantibacillus plantarum, Pediococcus acidilactici

\section{Background}

The lactobacilli (or family Lactobacillaceae until 2020) are a highly diverse group of lactic acid-producing bacteria. Species within this group were formerly classified into only three genera, Lactobacillus, Paralactobacillus, and Pediococcus, and were only recently re-classified into 26 different genera, including the genera Lactiplantibacillus (formerly Lactobacillus) and Pediococcus [1]. They can be found in many ecological niches, such as on living and decaying plant material, as well as in naturally fermented meat, vegetables, milk and silages [2, 3]. Colonization of the digestive tract of mammalian hosts by members of the lactobacilli is also frequently observed $[4,5]$. Some species of lactobacilli are "generally recognized as safe", and these are some of the economically most important species as they are routinely used in a variety of industrial food and feed fermentations [6]. Many beneficial effects for human and animal health have been attributed to these species, some of which are supported by a large body of scientific literature, e.g., elimination of pathogens through lactic acid and bacteriocin production [7, 8], production of beneficial metabolites and vitamins [9], reduction of cholesterol [10], antioxidant activity [11], as well as a broad range of other health promoting and disease preventing effects $[12,13]$. Moreover, fermented food and feed are generally characterized by an enhanced texture, flavor, aroma and nutritional value, due to the abundance and diversity of secreted metabolites (e.g., organic acids, ketones, and aldehydes) and enzymes (e.g., amylases, esterases, glucosidases, lipases, and proteases) $[14,15]$. Proteases have been intensively studied in lactobacilli [16-19]. Proteases catalyze the hydrolysis of peptide bonds of proteins that are present in complex food and feed matrices. This process results in the release of peptides and free amino acids essential for cell growth. Hence, protease activity is particularly important to those species auxotrophic for amino acids, which often occur in milk fermentations [17]. Proteolytic activity improves dietary protein digestibility and nutrient utilization by increasing the relative amount of small peptides [20]. Moreover, proteases break down allergenic proteins and trypsin inhibitors, e.g., in soybean-derived substrates, which results in improved acceptance and higher uptake especially by monogastric animals [21]. In addition, proteases contribute to flavor and texture of fermented products [18]. For these reasons, investigations into the diversity and activity of native proteolytic enzymes in lactic acid bacteria has been a focal point of research for several decades [18]. However, most species harbor cell envelope-associated proteinase, and its attachment to the cell wall limits the amount of protease produced $[17,18]$. Lactiplantibacillus plantarum and Pediococcus acidilactici are two of the industrially most important species in food and feed fermentation [2]. Several studies have explored the possibility of improving enzyme activity via genetic engineering using these two species as models [22]. One of the most critical parameters to determine if secretion of a desired target protein will be successful or not is the capacity of the signal peptide used to transport the protein into the extracellular space [23]. So far, engineered secretion in L. plantarum and P. acidilactici has mostly been achieved via heterologous signal peptides, e.g., sslipA of Bacillus subtilis [24], M6 of Streptococcus pyogenes [25] and Usp45 of Lactococcus lactis [26]. Only a limited number of studies have focused on the identification of homologous signal peptides in L. plantarum [27], and, to the best of our knowledge, none are available for $P$. acidilactici yet. Native signal peptides, however, have been shown to lead to similar or higher secretion than constructs with heterologous signal peptides [28]. It is conceivable that native signal peptides are best recognized by the native secretory machinery of the host. One key problem in selecting suitable signal peptides is the difficulty in predicting their efficiency based on primary sequence information alone. In this study, we carried out a genome-wide analysis of signal peptides from $L$. plantarum and P. acidilactici. Predicted native signal peptides were then assessed in L. plantarum or P. acidilactici host strain for their capacity in directing secretion of heterologous protease PepG 1[29]. Several novel native signal peptides were identified that resulted in recombinant strains with improved protease secretion. Use of these strains may increase extracellular protein degradation and peptide content in food and feed matrices.

\section{Results \\ Plasmid optimization}

In recent years, numerous plasmid vectors have been constructed for members of the former genus Lactobacillus [30-32]. However, advanced cloning vectors with high transformation efficiency and structure stability in E. coli, Lactiplantibacillus (Lactobacillus) plantarum 
and Pediococcus acidilactici are still lacking. In order to construct a shuttle vector, an $E$. coli replicon, an $E$. coli selection marker, a lactobacilli replicon and a lactobacilli selection marker are required.

pUC57 was selected for its E. coli replicon and antibiotic resistance gene. In lactic acid bacteria, the most common replication mechanisms are the rolling circle and theta modes of replication [31]. Rolling circle mode of replicons, pSH71 [33], pWV01 [32, 34] and pLAB1000 [35], and theta type of replicons, $\mathrm{pAm} \beta 1$ [30] and p256 [36] were selected. Among all five replicons, pSH71 and pWV01 suffered from structural instability during cloning in E. coli, as demonstrated by reduced plasmid size (data not shown), which is consistent with other reports [31]. Among pAm $\beta 1$, pLAB1000 and p256, only p256 showed successful expression of GusA in both L. plantarum and $P$. acidilactici, while pAm $\beta 1$ and pLAB1000 only showed positive colonies in L. plantarum or P. acidilactici, respectively. Thus, p256 was ligated into the MCS site of pUC57. Then, a $2948 \mathrm{bp}$ fragment carrying the erythromycin selection marker $\left(\mathrm{Erm}^{\mathrm{R}}\right)$ and reporter gene GusA from pTRK892m was ligated to pUC256, resulting in shuttle vector pUC256E (Fig. 1). GusA was used to assess the potential of the expression system in lactobacilli. Upon expression, clear 5-bromo-4-chloro3 -indolyl glucuronide (X-Gluc) changes to a blue color. The appearance of blue-colored colonies on the agar suggested that pUC256E successfully expressed GusA. Successful plasmid construction was confirmed by sequencing. Subsequently, pUC256E was used for protease expression and signal peptide screening in L. plantarum and $P$. acidilactici.

\section{Protease expression and secretion in L. plantarum and $P$. acidilactici}

Lactobacilli are known for their production of lactic acid during growth, which leads to a lowered $\mathrm{pH}$ of the culture media. Five proteases, NprB from Bacillus subtilis (GenBank accession number: CAB01832.1), PepJ from Aspergillus nidulans (UniProtKB accession number: Q5AUR8.1), PepG1 from Alicyclobacillus sp. (GenBank accession number: ADG26771.1), PepA from Aspergillus awamori (PepA-Aa) (GenBank accession number: AAA78947.1) and PepA from Aspergillus niger (PepAAn) (GenBank accession number: CAK42031.1), were chosen based on the fact that those proteases show optimum protease activity at low $\mathrm{pH}$, mainly between $\mathrm{pH} 4-5$ [29, 37-40]. However, in order to hydrolyse the proteinaceous substrate in the media, a signal peptide is needed to initiate protease secretion. Here, a widely known $L$. plantarum signal peptide LP_0373, the best-performing native signal peptide of L. plantarum WCFS1 for secretion of model proteins NucA and AmyA, was selected as a benchmark [28]. To construct plasmids carrying these proteases, the ribosome binding site AGGAGG, signal peptide LP_0373 and respective protease were cloned into pUC256E by replacing the GusA coding sequence. The remaining pgm promoter at the $5^{\prime}$ end and Term 908 terminator at $3^{\prime}$ end of GusA were utilized as promoter and terminator for protease expression. Some studies have demonstrated that the fusion of a propeptide in-between the signal peptide and the mature moiety can enhance protein secretion [41, 42]. Therefore, in this experiment, we tested the effect of a propeptide by comparing protease secretion of constructs with and without the native propeptide in front of the mature protein. Proteins in supernatant and intracellular proteins were extracted and analysed by western blotting. Among all ten tested proteases, only PepG1 with and without the propeptide sequence $(25.9 \mathrm{kDa}, 23.3 \mathrm{kDa}$ respectively) could be expressed and secreted in both $L$. plantarum and $P$. acidilactici (Fig. 2A). Only PepG1 without propeptide gave protease activity in both $L$. plantarum and $P$. acidilactici, therefore, PepG1 was chosen for further screening.

To increase protease secretion, we tested extracellular protease activity of four other well-known heterologous signal peptides, i.e. LP_0600 from L. plantarum [28], sslipA from B. subtilis [24], M6 from Streptococcus pyogenes [25] and Usp45 from Lactococcus lactis [26] in both L. plantarum (Fig. 2B) and P. acidilactici (Fig. 2C). All four signal peptides resulted in lower protease activity compared to LP_0373 in both L. plantarum and P. acidilactici. Therefore, homologous signal peptide screening was performed to increase protease secretion efficiency.

\section{Library construction}

Secretion performance of signal peptides strongly depends on the expression host and target protein [25, 26]. Therefore, in this study, genomic scale prediction of native signal peptides was performed for our selected host strains. Native signal peptides of $L$. plantarum and $P$. acidilactici were predicted by SignalP using their proteome sequences as input. SignalP is a web-based program, which uses a deep neural network-based method incorporating conditional random field classification and improved transfer learning for optimized signal peptide prediction [43]. A total of 155 and 110 potential signal peptides were identified in L. plantarum and P. acidilactici, respectively. The length of the predicted signal peptides varied from ten to 49 amino acids for L. plantarum (30.0 \pm 6.7 amino acids), among which LP_25440 was the shortest, and LP_23420 and LP_02480 were the longest. For $P$. acidilactici, the length of signal peptides varied from 16 to 52 amino acids (30.8 \pm 7.7 amino acids), with PA_02840 being the shortest and PA_13520 being 


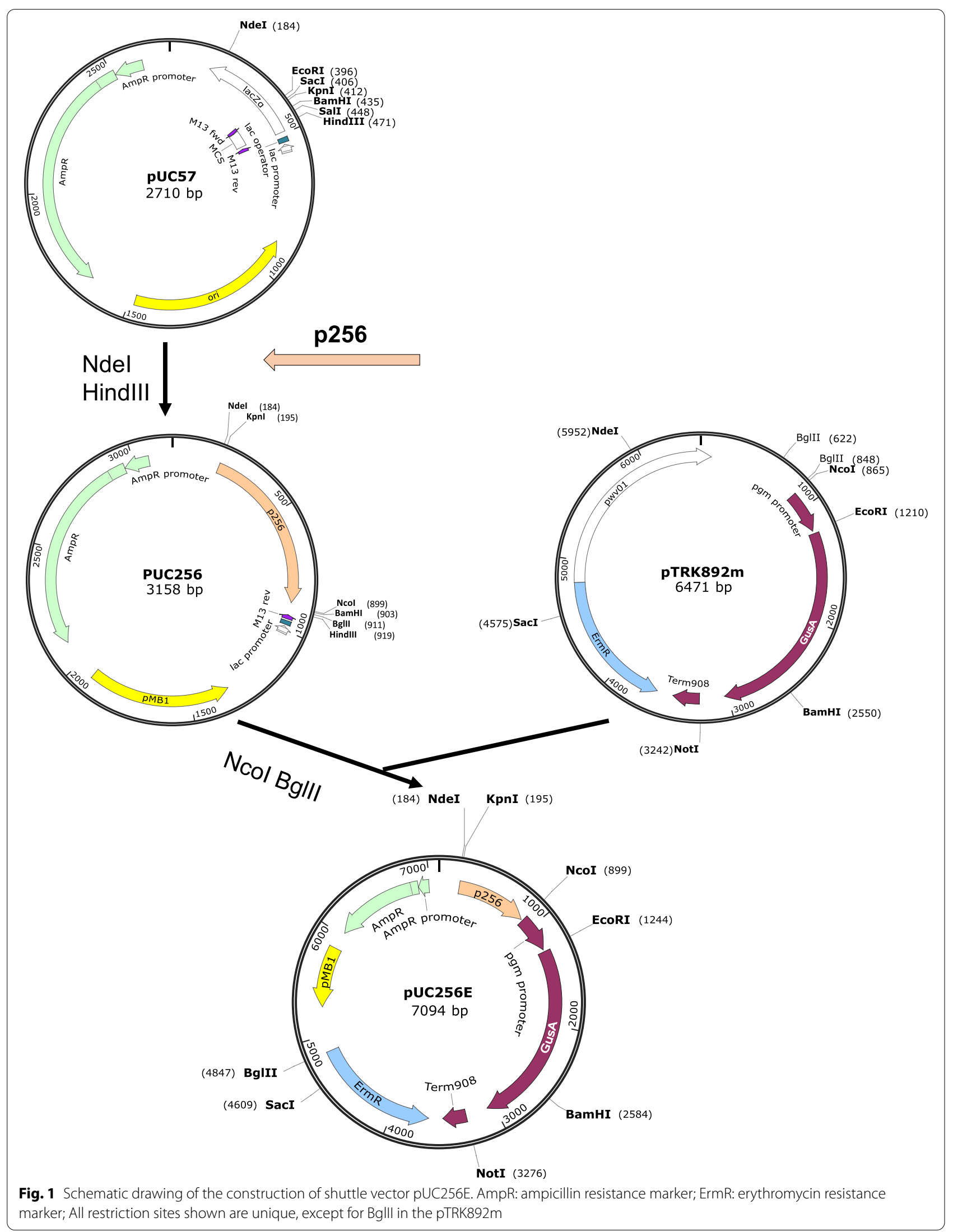




\section{A}

\section{L. plantarum P. acidilactici}

PepG1 pro-PepG1

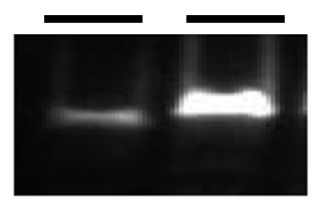

B

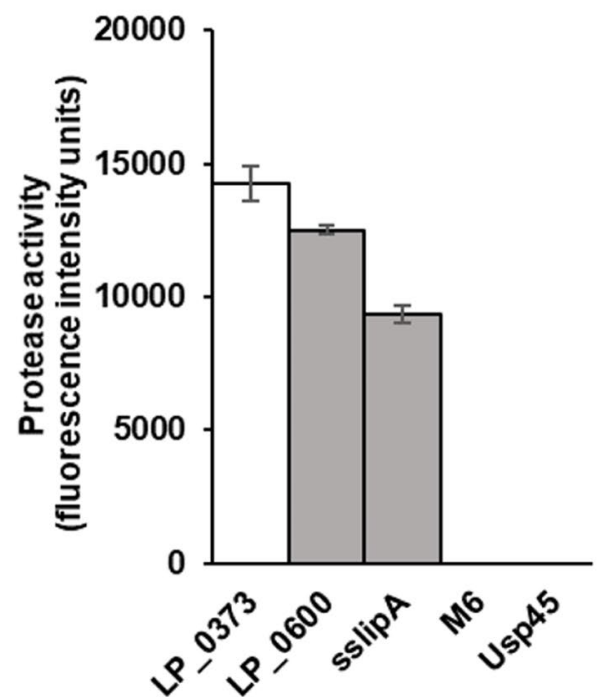

PepG1 pro-PepG1

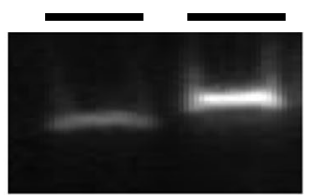

C

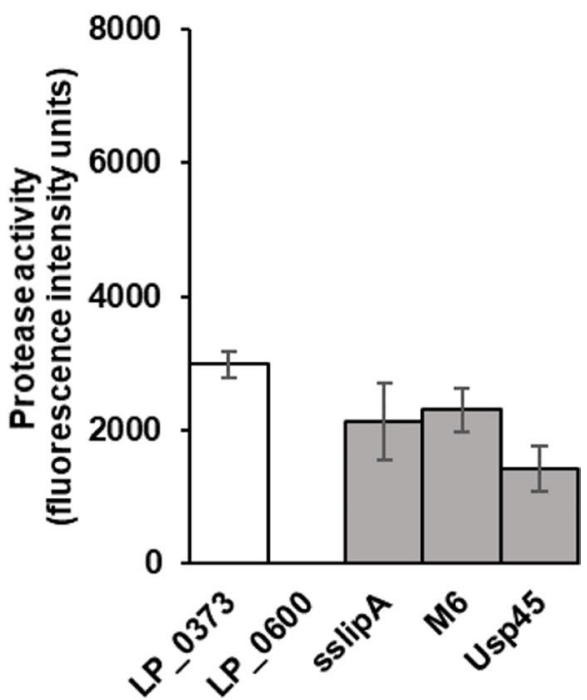

Fig. 2 Protease expression and secretion in L. plantarum and P. acidilactici. A PepG1 and pro-PepG1 (PepG1 with propeptide) were expressed and secreted in both L. plantarum and P. acidilactici confirmed by western blot analysis. The protein bands corresponded to a molecular mass around $23 \mathrm{kDa}$, as deduced from positions of molecular weight standards (Bio-Rad; Precision Plus Protein Standards, not shown) and thus corresponded to mature PepG1. The protein bands of pro-PepG1 were visualized at slightly higher position on the gel due to the presence of the $2.6 \mathrm{kDa}$ propeptide. For clarity and conciseness, blots of PepG1 and pro-PepG1 of L. plantarum were cropped from the image of the same gel, while blots of PepG1 and pro-PepG1 of P. acidilactici were cropped from the image of a second gel. The two blots were processed in parallel with the same exposure time $(60$ s). Full-length blots are presented in Supplementary Fig. S1. Protease activities in supernatants of L. plantarum (B) and P. acidilactici (C) harboring plasmids with different heterologous signal peptides. The white bars represent LP_0373, the control signal peptide chosen in this study. Enzyme activities are expressed in fluorescence intensity units. All results represent the means of three independent experiments; the error bars indicate the standard deviation (SD)

the longest. Bacterial signal peptides tend to have a prevalence of alanine at positions -3 and -1 relative to the cleavage site, giving rise to the name of the motif, Ala-XAla [44-46]. A total of 53 (out of 155) L. plantarum signal peptides have the consensus Ala-X-Ala cleavage site, while 32 (out of 110) P. acidilactici signal peptides contain the Ala-X-Ala cleavage site.

The respective signal peptides were fused to the $\mathrm{N}$-terminal of PepG1 gene and downstream of pgm promoter. At the C-terminal of the signal peptide, two amino acids downstream of the predicted cleavage site were retained from the original protein. The cloning work was performed in E. coli cells. After transformation, selected colonies were sent for sequencing to confirm the diversity of the secretion tags in plasmids. Subsequently, over 2000 E. coli colonies were washed out and plasmids were extracted. After the preparation of the plasmid library, the cell libraries were created by transforming a mixture of the respective plasmids into L. plantarum or P. acidilactici cells. Notably, as opposed to $P$. acidilactici, transformation efficiency was poor for $L$. plantarum with the plasmids extracted from DH5 $\alpha$. Genome analysis revealed that $L$. plantarum SH LP contains a type IV restriction modification (R-M) system, which degrades methylated foreign DNAs. R-M systems in bacteria act as important defence mechanisms against invading 
genomes $[47,48]$. To solve this issue, E. coli C2925 was chosen for unmethylated plasmid preparation, resulting in at least 1000-fold improved transformation efficiency of L. plantarum.

\section{Screening of signal peptides for improved PepG1 secretion capacity in L. plantarum}

After confirming signal peptide diversity in transformants, a total of $1630 \mathrm{~L}$. plantarum colonies (>10-fold oversampling) were obtained and picked for screening. The strain harboring the expression vector with the LP_0373 signal peptide was used as the control. Protease activity was determined from the collected culture supernatants. A total of eighteen 96-well plates were screened to assess protease activity of all colonies. We shortlisted 126 colonies that showed $\geq 20 \%$ improved secretion capacity over the control signal peptide. Their plasmids were isolated and sequenced to determine the present signal peptides. Based on the sequencing results (Supplementary Table S1), a total of 12 different signal peptides were identified as potential candidates for improving the secretory expression of PepG1 in L. plantarum (Table 1).

To confirm the superior capacity of the signal peptides selected from the first round of screening on the PepG1 secretion level in L. plantarum, we re-evaluated the cells containing these signal peptides in triplicate. The cells containing LP_23790 and LP_08330 showed the highest secretion capacity. Their secretion efficiency was 18 and 17\% higher than that of LP_0373 respectively, with $p$-value $<0.05$ (Student's $t$-test; Fig. 3$)$. Compared to LP_0373, both LP_04240 and LP_23670 showed a higher secretion on average, however, the increase was not significant. The remaining seven signal peptides had lower capacities than LP_0373 (Fig. 3).

\section{Screening of signal peptides for improved PepG1 secretion capacity in $P$. acidilactici}

The screening process for secretion capacity of PepG1 in $P$. acidilactici with its homologous signal peptide library was similar to that used for L. plantarum, and the same control, LP_0373, was used. A total of 1179 clones ( $>10$-fold oversampling) were selected and screened for protease activity. Out of these, 44 clones showed $\geq 50 \%$ improved protease activity and were sent for DNA sequencing to deduce the signal peptide sequences (Supplementary Table S1). A total of eight signal peptide sequences were retrieved, and cells carrying these were subjected to a second round of screening (Table 1).

Except for PA_07000, all homologous signal peptides achieved significantly higher secretion capacity than heterologous LP_0373 ( $p<0.05$, Student's $t$-test). PA_18600 showed the highest secretion capacity, which was $80 \%$ higher than that of the control LP_0373 (Fig. 4).

\section{Correlations between signal peptide properties and measured secretion capacity for PepG1 protease}

To further explore the potential correlation between the properties of the best-performing signal peptides and their high secretion capacity, we compared the 20 signal peptides with the highest protease secretion with nine signal peptides with no secretion activity identified during the screening process. It is known that signal peptides consist of three specific domains: a positively charged $\mathrm{N}$-domain, a hydrophobic $\mathrm{H}$-domain, and a neutral but polar C-domain containing the three amino acids which form the signal peptidase recognition site [27]. Here, several different properties of signal peptides were selected for analysis, namely, length, net charge of the $\mathrm{N}$-domain, hydrophobicity, presence of an Ala-X-Ala cleavage site and transmembrane helix structure (Table 1).

Statistical analysis did not result in any significant differences between the two groups of signal peptides. These results are consistent with other studies [27, 49] which have shown that for specific protein, evaluation of signal peptide performance based on its amino acid sequence only proved to be an uphill task.

\section{Pertinence of identified active signal peptides in other strains and similarity of predicted signal peptides within species and genera}

To understand the distribution and potential applicability of our identified active signal peptides, we assessed their presence in other strains and phylogenetically closely related species. Nine out of 12 identified L. plantarum signal peptides were present in more than half of the analyzed $L$. plantarum genomes, while the $P$. acidilactici signal peptides were detected in less than $60.9 \%$ of the analyzed $P$. acidilactici genomes (Table 2). In addition, seven out of $12 \mathrm{~L}$. plantarum signal peptides appeared in other Lactiplantibacillus species, while none of the $P$. acidilactici signal peptides were present in other Pediococcus species (Table 2). It appears that the signal peptides identified in L. plantarum SH LP are more widely distributed than those identified in P. acidilactici SH PA.

The similarity of signal peptides between the strains of the same and different species is shown for L. plantarum and $P$. acidilactici in Supplementary Fig. S2A and $\mathrm{B}$, respectively. Both, $L$. plantarum and $P$. acidilactici showed a high similarity of predicted signal peptides across strains belonging to the same species. The average similarities ( \pm standard deviation) across strains of $L$. plantarum and P. acidilactici were $51.1 \pm 8.4 \%$ and $45.3 \pm 14.6 \%$, respectively. When comparing with strains of other species or even genera, the similarity of predicted signal peptides decreased, with a considerably steeper decrease noticed within the genus Pediococcus compared to the genus Lactiplantibacillus. For 
Table 1 Characteristics of the signal peptides identified in the screening

\begin{tabular}{|c|c|c|c|c|c|c|c|}
\hline $\begin{array}{l}\text { Signal } \\
\text { peptide }\end{array}$ & $\begin{array}{l}\text { Amino acid sequence (putative } \\
\text { cleavage site indicated by arrow) }\end{array}$ & $\begin{array}{l}\text { Predicted } \\
\text { function for } \\
\text { corresponding } \\
\text { protein }\end{array}$ & $\begin{array}{l}\text { Length } \\
\text { (amino } \\
\text { acid) }\end{array}$ & $\begin{array}{l}\text { Net } \\
\text { charge of } \\
\text { N-domain }\end{array}$ & $\begin{array}{l}\text { Hydrophobicity } \\
(\%)\end{array}$ & $\begin{array}{l}\text { Ala-X-Ala } \\
\text { motif }\end{array}$ & $\begin{array}{l}\text { Transmembrane } \\
\text { helix }\end{array}$ \\
\hline \multicolumn{8}{|c|}{ Signal peptide with protease secretion } \\
\hline LP_23790 & $\begin{array}{l}\text { MKKFNFFKTMLLLVLASCVFGVVVNVTTS } \\
\text { LGPQTTITAQA } \downarrow S K\end{array}$ & transglycosylase & 39 & 3 & 59 & $\checkmark$ & $\checkmark$ \\
\hline LP_08330 & $\begin{array}{l}\text { MIKLRQVLKKILIVLMVFVLVFTAFSSSVD } \\
\text { TVSA } \downarrow H R\end{array}$ & $\begin{array}{l}\text { hypothetical } \\
\text { protein }\end{array}$ & 34 & 4 & 65 & & $\checkmark$ \\
\hline LP_04240 & $\begin{array}{l}\text { MKKLMCLFGVIGGLVFMSWTSPSIQA } \\
\text { TA } \downarrow T N\end{array}$ & $\begin{array}{l}\text { cell surface } \\
\text { protein }\end{array}$ & 28 & 2 & 68 & $\checkmark$ & $\checkmark$ \\
\hline LP_23670 & $\begin{array}{l}\text { MQLLKRIMVIVGTLILGLQVSSVSGLA } \\
\downarrow A S\end{array}$ & $\begin{array}{l}\text { cell surface } \\
\text { protein }\end{array}$ & 27 & 2 & 70 & & $\checkmark$ \\
\hline LP_28190 & $\begin{array}{l}\text { MKRLRHIKLGMLLLSCLAFISMLAITSQ } \\
\text { A } \downarrow A A\end{array}$ & $\begin{array}{l}\text { extracellular } \\
\text { protein }\end{array}$ & 29 & 4 & 62 & & $\checkmark$ \\
\hline LP_29340 & $\begin{array}{l}\text { MRKWQVAVVMLLAALGSWFAIGTQA } \\
\text { QA } \downarrow K T\end{array}$ & $\begin{array}{l}\text { glutamine } A B C \\
\text { transporter sub- } \\
\text { strate binding, } \\
\text { permease }\end{array}$ & 27 & 2 & 74 & $\checkmark$ & $\checkmark$ \\
\hline LP_23680 & MPNKWWRLILGVMLVLSWAIPVRA $\downarrow A T$ & $\begin{array}{l}\text { cell surface } \\
\text { protein }\end{array}$ & 24 & 2 & 79 & & $\checkmark$ \\
\hline LP_28170 & $\begin{array}{l}\text { MKKMMRWLGAILVMISGLSAVVPAQ } \\
\text { A } \downarrow \text { AN }\end{array}$ & $\begin{array}{l}\text { cell surface } \\
\text { protein }\end{array}$ & 26 & 3 & 77 & $\checkmark$ & $\checkmark$ \\
\hline LP_23160 & $\begin{array}{l}\text { MQKRLRLSLGMLLAVVASLLMMGQV } \\
\text { ASA } \downarrow D Q\end{array}$ & $\begin{array}{l}\text { hypothetical } \\
\text { protein }\end{array}$ & 28 & 3 & 71 & $\checkmark$ & $\checkmark$ \\
\hline LP_24320 & $\begin{array}{l}\text { MRFAGKLKKVMIALVAAVTFSTAGLGIAG } \\
\text { ADLQAQA } \downarrow A S\end{array}$ & $\begin{array}{l}\text { D-alanyl-D-ala- } \\
\text { nine carboxy- } \\
\text { peptidase }\end{array}$ & 36 & 4 & 72 & $\checkmark$ & $\checkmark$ \\
\hline LP_14210 & $\begin{array}{l}\text { MKKIVNWLLGSVLMIAAVTMLSSVSA } \\
\text { NA } \downarrow S T\end{array}$ & $\begin{array}{l}\text { hypothetical } \\
\text { protein }\end{array}$ & 28 & 2 & 68 & $\checkmark$ & $\checkmark$ \\
\hline LP_09710 & $\begin{array}{l}\text { MRRLLTGTLVVGGLLLVVCLMAVNGQ } \\
\text { A } \downarrow \text { KV }\end{array}$ & $\begin{array}{l}\text { extracellular } \\
\text { protein }\end{array}$ & 27 & 2 & 74 & & $\checkmark$ \\
\hline PA_18600 & $\begin{array}{l}\text { MVKSRNRILHYILVAVSVIVVLGFSVIK } \\
\text { ASA } \downarrow H G\end{array}$ & $\begin{array}{l}\text { chitin-binding } \\
\text { protein }\end{array}$ & 32 & 3 & 66 & $\checkmark$ & $\checkmark$ \\
\hline PA_13510 & $\begin{array}{l}\text { MYKGFKKYFSNGADRKAGNYPVAKR } \\
\text { NKRWLLASAVMLAMFGAGMAQSHA } \\
\text { FA } \downarrow K A\end{array}$ & $\begin{array}{l}\text { hypothetical } \\
\text { protein }\end{array}$ & 51 & 9 & 59 & $\checkmark$ & $\checkmark$ \\
\hline PA_18250 & $\begin{array}{l}\text { MKLKAKLLLVVVPFLMGSWVYHPTPTV } \\
\text { QA } \downarrow K T\end{array}$ & $\begin{array}{l}\text { DNA-entry } \\
\text { nuclease }\end{array}$ & 29 & 3 & 69 & & $\checkmark$ \\
\hline PA_08950 & $\begin{array}{l}\text { MNQNWQKPSPKLNWVRFYSIVTILVLVT } \\
\text { SVAGLEMLRVSA } \downarrow H Q\end{array}$ & $\begin{array}{l}\text { beta-lactamase } \\
\text { class A }\end{array}$ & 40 & 3 & 58 & & $\checkmark$ \\
\hline PA_17320 & $\begin{array}{l}\text { MKKARWKLLLAGLALLGGISLGQNIIS } \\
\text { A } \downarrow N T\end{array}$ & $\begin{array}{l}\text { hypothetical } \\
\text { protein }\end{array}$ & 28 & 4 & 71 & & $\checkmark$ \\
\hline PA_10610 & $\begin{array}{l}\text { MKRKWFSLLVAVFLIIGVAIGFGGILHSK } \\
\text { SSG } \downarrow N D\end{array}$ & $\begin{array}{l}\text { hypothetical } \\
\text { protein }\end{array}$ & 32 & 3 & 72 & & $\checkmark$ \\
\hline PA_04150 & $\begin{array}{l}\text { MKKAITTASFFLAIFVVFMVGSNAAS } \\
\text { A } \downarrow \text { KS }\end{array}$ & $\begin{array}{l}\text { hypothetical } \\
\text { protein }\end{array}$ & 27 & 2 & 70 & $\checkmark$ & $\checkmark$ \\
\hline PA_07000 & $\begin{array}{l}\text { METKKRFKMYKSGKKWLVAAIVAGGIAT } \\
\text { AGSVASVNA } \downarrow D E\end{array}$ & $\begin{array}{l}\text { hypothetical } \\
\text { protein }\end{array}$ & 38 & 7 & 59 & & $\checkmark$ \\
\hline \multicolumn{8}{|c|}{ Signal peptide without protease secretion } \\
\hline LP_27290 & $\begin{array}{l}\text { MRRKLVGYMLSMLTVILALFMLGSTA } \\
\text { HA } \downarrow K E\end{array}$ & $\begin{array}{l}\text { cell surface } \\
\text { protein }\end{array}$ & 28 & 3 & 68 & $\checkmark$ & $\checkmark$ \\
\hline LP_27220 & $\begin{array}{l}\text { MKKINKLMILGMLVLGVTGATMINPEM } \\
\text { TTA } \downarrow A H\end{array}$ & $\begin{array}{l}\text { extracellular } \\
\text { protein }\end{array}$ & 30 & 3 & 67 & & $\checkmark$ \\
\hline LP_17340 & $\begin{array}{l}\text { MKKRFGWFLAIIVALIMTVVPLGQTQH } \\
\text { AQA } \downarrow A D\end{array}$ & $\begin{array}{l}\text { ABC transporter } \\
\text { substrate- } \\
\text { binding and } \\
\text { permease } \\
\text { protein }\end{array}$ & 30 & 3 & 70 & $\checkmark$ & $\checkmark$ \\
\hline
\end{tabular}


Table 1 (continued)

\begin{tabular}{|c|c|c|c|c|c|c|c|}
\hline $\begin{array}{l}\text { Signal } \\
\text { peptide }\end{array}$ & $\begin{array}{l}\text { Amino acid sequence (putative } \\
\text { cleavage site indicated by arrow) }\end{array}$ & $\begin{array}{l}\text { Predicted } \\
\text { function for } \\
\text { corresponding } \\
\text { protein }\end{array}$ & $\begin{array}{l}\text { Length } \\
\text { (amino } \\
\text { acid) }\end{array}$ & $\begin{array}{l}\text { Net } \\
\text { charge of } \\
\text { N-domain }\end{array}$ & $\begin{array}{l}\text { Hydrophobicity } \\
\text { (\%) }\end{array}$ & $\begin{array}{l}\text { Ala-X-Ala } \\
\text { motif }\end{array}$ & $\begin{array}{l}\text { Transmembrane } \\
\text { helix }\end{array}$ \\
\hline LP_11950 & $\begin{array}{l}\text { MTKRMSFKFKWVALVATLIVGIGSWQV } \\
\text { LAHA } \downarrow D S\end{array}$ & $\begin{array}{l}\text { hypothetical } \\
\text { protein }\end{array}$ & 31 & 4 & 68 & $\checkmark$ & $\checkmark$ \\
\hline LP_12630 & $\begin{array}{l}\text { MLKLIKQRLVWGLVLTATVSGVLSCNVA } \\
\text { AHA } \downarrow T S\end{array}$ & $\begin{array}{l}\text { D-alanyl-D-ala- } \\
\text { nine carboxy- } \\
\text { peptidase }\end{array}$ & 31 & 3 & 65 & $\checkmark$ & $\checkmark$ \\
\hline LP_28330 & $\begin{array}{l}\text { MKLSKRGLFWLLGLVSFAILLLFSQPLG } \\
\text { AQA } \downarrow A T\end{array}$ & $\begin{array}{l}\text { cell surface } \\
\text { protein }\end{array}$ & 31 & 3 & 74 & $\checkmark$ & $\checkmark$ \\
\hline LP_27010 & $\begin{array}{l}\text { MRKLIKACGLMVISMLVGLGIVTSALA } \\
\downarrow A K\end{array}$ & $\begin{array}{l}\text { cell surface } \\
\text { protein, CscB } \\
\text { family }\end{array}$ & 27 & 3 & 74 & $\checkmark$ & $\checkmark$ \\
\hline PA_14540 & $\begin{array}{l}\text { MKNNKIIITAAIAGLLGGGVAYGGASFVQ } \\
\text { NRMEA } \downarrow T T\end{array}$ & serine protease & 34 & 2 & 68 & & $\checkmark$ \\
\hline PA_15330 & $\begin{array}{l}\text { MNYRSILFTTAIATMGAFSFGHSPVSA } \\
\downarrow H S\end{array}$ & hydrolase & 27 & 1 & 59 & & \\
\hline \multicolumn{2}{|c|}{ Average (with protease secretion) } & & 31.5 & 3.4 & 68.2 & $\begin{array}{l}50 \% \text { with } \\
\text { motif }\end{array}$ & 100\% with helix \\
\hline \multicolumn{2}{|c|}{ Average (without protease secretion) } & & 29.9 & 2.8 & 68.1 & $\begin{array}{l}67 \% \text { with } \\
\text { motif }\end{array}$ & $89 \%$ with helix \\
\hline \multicolumn{2}{|c|}{ t-test (with and without protease secretion) } & & 0.34 & 0.25 & 0.99 & - & - \\
\hline
\end{tabular}

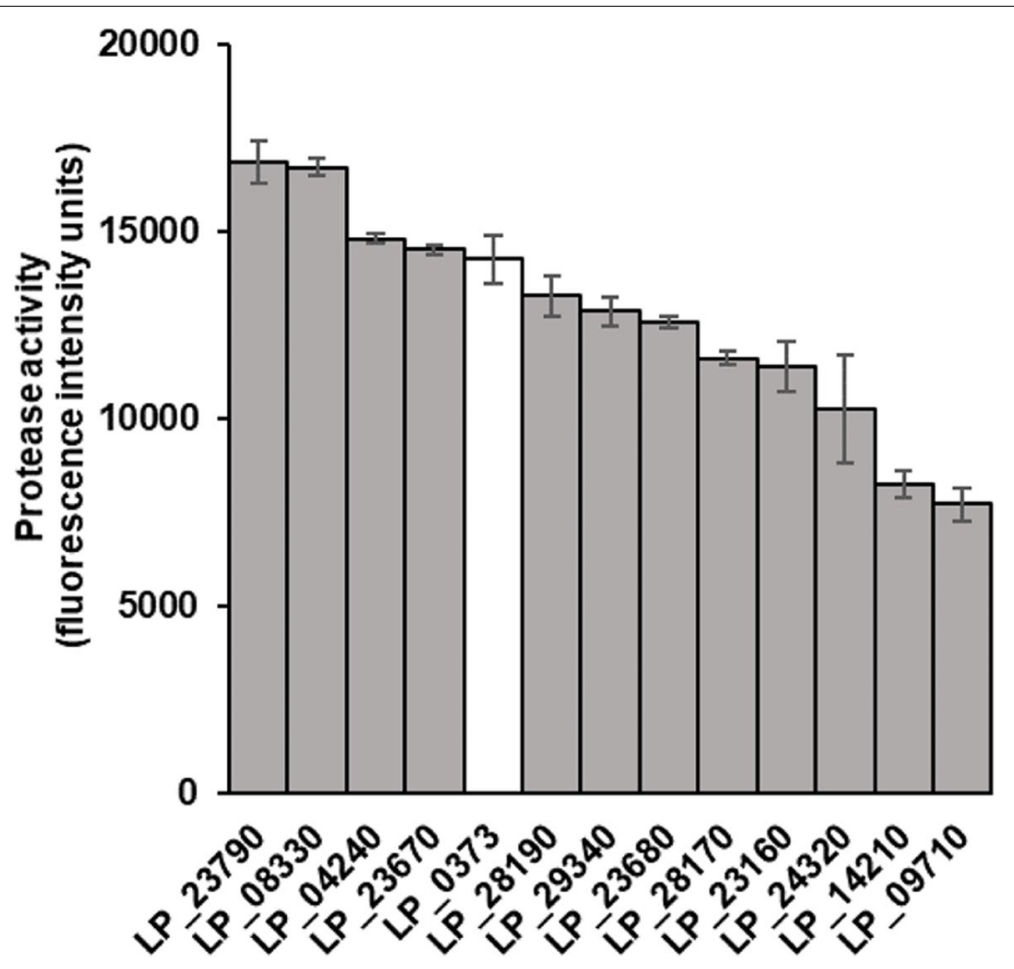

Fig. 3 Secretion capacity of PepG1 of homologous signal peptides in recombinant L. plantarum. Only secretion capacities of the 12 homologous signal peptides with the highest PepG1 secretion capacities in L. plantarum are shown. The white bar represents LP_0373, which was chosen as the benchmarking signal peptide in this study. Data shown represent the mean \pm SD of three biological replicates 


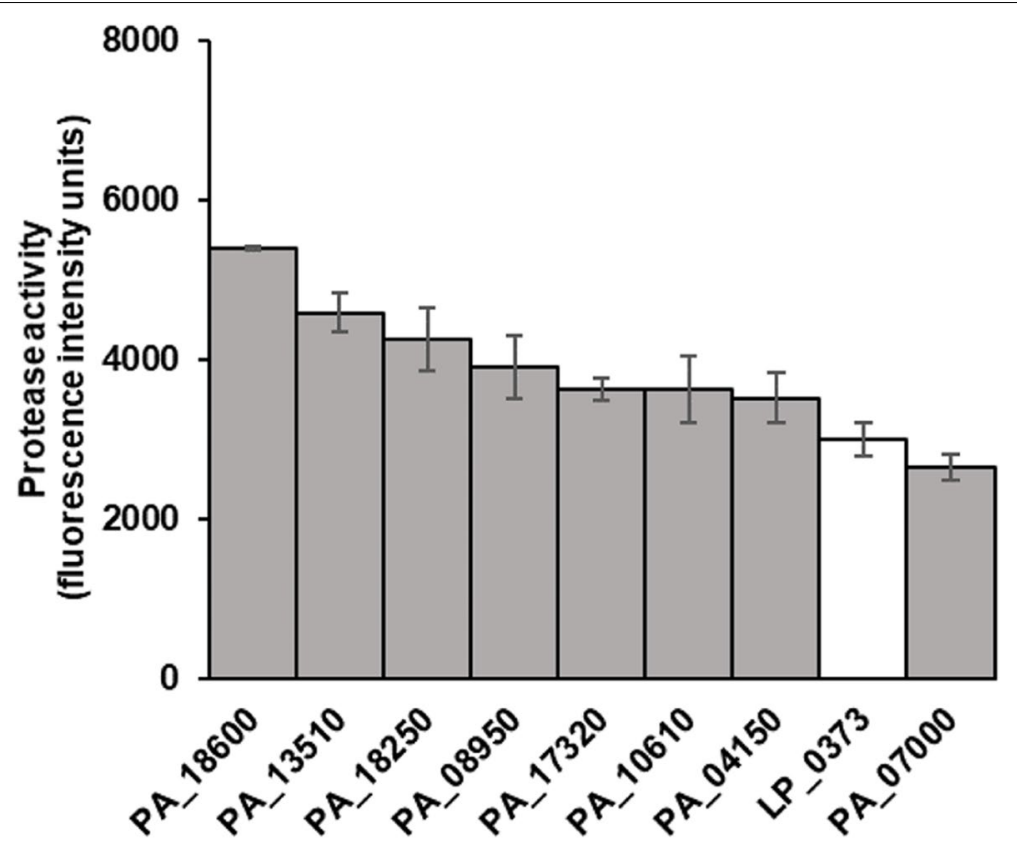

Fig. 4 Secretion capacity of PepG1 of homologous signal peptides in recombinant $P$. acidilactici. Only secretion capacities of the 8 homologous signal peptides with the highest PepG1 secretion capacities in P. acidilactici are shown. The white bar represents LP_0373, which was chosen as the benchmarking signal peptide in this study. Data shown represent the mean \pm SD of three biological replicates

Table 2 The presence of the identified signal peptides in other strains within the same species or the same genus

\begin{tabular}{lll}
\hline Signal peptide & $\begin{array}{l}\text { Presence of signal peptide in } \mathbf{1 5 6} \text { strains within } L^{.} \\
\text {plantarum species or } \mathbf{2 3} \text { strains within P. acidilactici species } \\
(\%)\end{array}$ & $\begin{array}{l}\text { Presence of signal peptide in } \mathbf{3} \text { strains of other } \\
\text { Lactiplantibacillus species or } \mathbf{4} \text { strains of other Pediococcus }_{\text {species }^{\mathbf{a}} \text { (\%) }}\end{array}$ \\
\hline LP_23790 & 71.8 & 33.3 \\
LP_08330 & 1.9 & 0.0 \\
LP_04240 & 3.8 & 33.3 \\
LP_23670 & 96.8 & 33.3 \\
LP_28190 & 83.3 & 0.0 \\
LP_29340 & 85.9 & 33.3 \\
LP_23680 & 91.0 & 33.3 \\
LP_28170 & 36.5 & 0.0 \\
LP_23160 & 52.6 & 33.3 \\
LP_24320 & 96.8 & 33.3 \\
LP_14210 & 85.3 & 0.0 \\
LP_09710 & 93.6 & 0.0 \\
PA_18600 & 47.8 & 0.0 \\
PA_13510 & 13.0 & 0.0 \\
PA_18250 & 60.9 & 0.0 \\
PA_08950 & 52.2 & 0.0 \\
PA_17320 & 21.7 & 0.0 \\
PA_10610 & 34.8 & 0.0 \\
PA_04150 & 26.1 & 0.0 \\
PA_07000 & 0.0 & 0.0 \\
\hline
\end{tabular}

${ }^{a}$ These are the only strains that have complete genome sequences in NCBI 
Lactiplantibacillus, the dendrogram derived from the signal peptide similarity matrix correlated well with the core genome phylogenetic tree [1].

\section{Discussion}

Extensive research has been conducted on the optimization of the secretory expression of proteins in Lactobacillales [50, 51]. However, secretion of heterologous proteins remains challenging. Previously, most studies have focused on the identification and use of heterologous signal peptides [22, 52, 53]. Here, we present a newly designed vector as a tool for secretion of proteins from Lactiplantibacillus plantarum and Pediococcus acidilactici, followed by comprehensive secretory activity testing of clones with plasmids harboring one of a total of 155 and 110 homologous putative signal peptides predicted from the genomes of L. plantarum and P. acidilactici, respectively.

Previously, numerous plasmid vectors have been constructed for various lactobacilli [30-32, 54]. However, the selection of replicons for plasmid construction are host strain dependent. Thus, in this study, five different replicons were tested in order to develop a stable and advanced shuttle vector for protein expression in L. plantarum and $P$. acidilactici. Replication of bacterial plasmids by a rolling-circle mechanism such as described for pSH71 and pWV01 avoids bulkiness of the vector due to its broad host-range. However, in our application, the use of the rolling-circle mechanism resulted in instability of the plasmid structure. Similarly, earlier work suggested that the formation of linear high-molecularweight plasmid multimers by rolling-circle replication was implicated in structure and segregational instability [55]. Therefore, we switched to a dual replicon strategy with both lactobacilli and E. coli replicons displayed in our vector. Moreover, to increase the ligation efficiency of the linearized backbone plasmid and DNA fragments of the signal peptide library, DNA assembly technology was used. Compared to the traditional digestion-ligation method, DNA assembly resulted in $>10$ times higher ligation efficiency. Furthermore, to increase transformation efficiency, the E. coli strain C2925, was chosen for construction of the L. plantarum plasmid library in this study. So far, E. coli C2925 has been a rather neglected strain for cloning. However, its unmethylated plasmids were easily transformed into L. plantarum due to its type IV restriction modification (R-M) system. Understanding the R-M system of the ultimate host strain can be an effective strategy to increase its transformation efficiency.

The same expression system was exploited for all five proteases tested here, and codon optimization was performed for proteases in our host strains. However, only PepG1 could be expressed and secreted in both $L$. plantarum and P. acidilactici. The issue of no expression of the four remaining proteases could be due to i) a complex mRNA secondary structure preventing interactions with the host's cellular machinery, leading to failed translation, ii) misfolding or unfolding due to lack of accurate post-translational modification, leading to fast degradation, or iii) toxicity of the protease due to its proteolytic activity when expressed inside the cell, and not secreted efficiently [56].

In this study, we used PepG1 as a model protein and studied secretion capacity with four typical heterologous signal peptides compared to homologous LP_0373. None of the heterologous signal peptides resulted in improved PepG1 secretion from strains L. plantarum and P. acidilactici. This result corroborates the consensus that a signal peptide's secretion capacity is difficult to predict based on its sequence properties [27, 28]. Thus, the construction of homologous signal peptide libraries and high-throughput screening seem to be a necessary and promising approach to identify the optimal signal peptide for the target protein.

For L. plantarum, 12 out of 155 signal peptides were selected for highest PepG1 secretion. LP_23790, the bestperforming signal peptide resulted in an $18 \%$ increase of protease activity in the culture media compared to LP_0373. Out of the 12 best-performing signal peptides, nine are novel signal peptides, among which LP_23670, LP_28190, LP_29340 and LP_14210 were previously undiscovered (less than 70\% similarity), while LP_23790, LP_08330, LP_04240 and LP_24320 demonstrate one amino acid difference with other known $L$. plantarum signal peptides [27]. Furthermore, nine out of 12 signal peptides originate from proteins with unknown functions (cell surface protein, extracellular protein and hypothetical protein). It would be interesting to understand the function of these native secretory proteins in the future.

Even though several common heterologous signal peptides have been tested in $P$. acidilactici for protein secretion [54], to the best of our knowledge, this is the first study of genome-wide analysis of homologous signal peptides of $P$. acidilactici. PA_18600 showed the highest secretion capacity ( $80 \%$ higher than the control LP_0373). All eight signal peptides identified here from $P$. acidilactici are novel signal peptides. These signal peptides may also be promising candidates for the expression and secretion of other heterologous proteins in $P$. acidilactici.

The analysis of secretion capacity and sequence properties of respective signal peptide did not reveal any distinctive predictive properties. Therefore, the characteristics that make a suitable signal peptide for a particular protein remain to be elucidated at the molecular level. Even though some studies suggested that an increase of 
the positive charge within the $\mathrm{N}$-domain and increased hydrophobicity of the H-domain could improve secretion in some bacteria [57], other studies delivered the opposite conclusion [58]. In consequence, instead of sitedirected mutagenesis to purposely change signal peptide properties, e.g., charge, polarity and hydrophobicity, saturation mutagenesis may be a more promising strategy to modify the amino acid sequence in a saturated manner in future studies [59]. In addition, a few studies have shown that directed evolution of signal peptides can improve target protein secretion. This work involved the fusion of $\mathrm{N}$-terminal signal peptide, target protein and $\mathrm{C}$-terminal $\beta$-lactamase, and selection of best candidates by choosing the survival mutants after application of ampicillin as selection pressure $[60,61]$. In addition, the secretion of a certain target protein is guarded by a complex pattern of events, involving a balance between biosynthesis, translocation and folding efficiency of the protein $[46,62]$. For example, linearization of the mRNA secondary structure near the ribosome binding site was reported to increase secretory expression levels [57], and different propeptides were tested for improved secretion yield of endopeptidase in both Lactococcus lactis [41, 63] and L. casei [42]. Taking into account the above considerations, modification of the ribosome binding site and $5^{\prime}$ end mRNA sequence, and propeptide and promoter library screening can be exploited to further increase protease secretion in the future.

\section{Conclusions}

In this study, plasmid, pUC256E, was developed for highthroughput screening of signal peptides in L. plantarum or P. acidilactici. Genome-wide experimental screening identified 20 signal peptides which show improved protease PepG1 secretion in either L. plantarum or $P$. acidilactici. The analysis of secretion capacity and sequence properties of respective signal peptide did not reveal any significant correlations. Therefore, it is not feasible to select the best-performing signal peptide for the target protein based on its amino acid sequence. The distribution of identified active signal peptides in other strains of the same species, and, in the case of $L$. plantarum, even in closely related species suggests their wider applicability. The genome-wide library screening approach presented in this study is an accessible and straightforward approach for high-throughput screening of signal peptides for the target protein.

\section{Methods}

\section{Strains and growth conditions}

Escherichia coli DH5 $\alpha$ (Invitrogen, Carlsbad, USA) and E. coli C2925 (dam $\left.{ }^{-} / \mathrm{dcm}^{-}\right)$(New England BioLabs, Ipswich, USA) cells were grown in LB (Lennox) broth
(Bio basic, Toronto, Canada) at $37^{\circ} \mathrm{C}$ under constant shaking. Lactiplantibacillus plantarum strain SH LP and Pediococcus acidilactici strain SH PA cells were grown stationary in MRS broth (Oxoid) with $0.1 \%$ Tween-80 $(\mathrm{w} / \mathrm{v})$ at $37^{\circ} \mathrm{C}$. Solid media were prepared with an addition of $1 \%$ agar $(\mathrm{w} / \mathrm{v})$ for LB plates, and $1.6 \%$ agar $(\mathrm{w} / \mathrm{v})$ for MRS plates. Antibiotics were added as follows: $100 \mu \mathrm{g} / \mathrm{ml}$ ampicillin for E. coli; $5 \mu \mathrm{g} / \mathrm{ml}$ erythromycin for L. plantarum and P. acidilactici.

\section{Plasmid construction}

The cloning skeleton for the new (shuttle) vector can be found in Table 3. Plasmids were constructed using standard molecular cloning techniques. Primers used in this study were purchased from Integrated DNA Technologies (Supplementary Table S2). Plasmid pUC256E was designed as a shuttle vector to propagate in E. coli, L. plantarum and $P$. acidilactici. Plasmid pUC57, which contains backbone elements for plasmid propagation in $E$. coli was chosen as a starting vector. E. coli replicon $\mathrm{pMB} 1$ and ampicillin resistance marker $\left(\mathrm{Amp}^{\mathrm{R}}\right)$ were retained in pUC57. For propagation in L. plantarum and $P$. acidilactici, plasmid pUC256 was derived from pUC57 by ligating a lactobacilli replicon p256 [36, 64], synthesized from Bio Basic (Toronto, Canada), to the multiple cloning site (MCS). Erythromycin resistance marker $\left(\mathrm{Erm}^{\mathrm{R}}\right)$, and reporter gene $\beta$-glucuronidase (GusA) including lactobacilli phosphoglycerate mutase promoter (pgm promoter) and terminator (Term 908) were amplified from pTRK892m, an SaII mutated version of pTRK892 [32], and subsequently inserted into pUC256 using restriction sites NcoI and BglII, resulting in plasmid pUC256E. The 17 vectors that were generated in this study together with the plasmid library are shown in Table 3.

\section{Signal peptide cloning, assembly and transformation}

Genomic DNA was extracted by using bead-beating in combination with the Maxwell DNA extraction system. Briefly, $150 \mu$ of an overnight culture of L. plantarum or $P$. acidilactici were transferred into bead-beating tubes (MP Biomedicals LLC, Irvine, USA) together with $500 \mu \mathrm{l}$ 1\% SDS and $20 \mu \mathrm{l}$ Protease K (Promega, Madison, USA). Bead-beating was performed at $6.0 \mathrm{~m} / \mathrm{s}$ for $40 \mathrm{~s}$ using the FastPrep system (MP Biomedicals LLC, Irvine, USA). The sample was centrifuged at $16,000 \times \mathrm{g}$ for $6 \mathrm{~min}$. The supernatant was transferred into the first well of the Maxwell cartridge containing $300 \mu$ of lysis buffer, and all subsequent steps were done as described in the manufacturer's protocol (Maxwell 16 FFS Nucleic Acid Extraction System, Promega, Madison, USA). DNA was eluted into a total volume of $80 \mu$ l elution buffer $(10 \mathrm{mM}$ Tris, pH 8.5 with $\mathrm{HCl})$. Whole genome 
Table 3 Plasmids used in this study

\begin{tabular}{|c|c|c|}
\hline Plasmids & Relevant characteristics & Source \\
\hline pUC57 & $A m p^{R}, p M B 1$ origin; cloning vector skeleton for shuttle vector & Bio Basic \\
\hline pUC256 & Amp ${ }^{R}, p M B 1$ origin, p256 orgin & This study \\
\hline pUC256E & $\mathrm{Amp}^{R}, \mathrm{Erm}^{\mathrm{R}}, \mathrm{pMB} 1$ origin, $\mathrm{p} 256$ orgin, GusA reporter & This study \\
\hline pUC256E-sp LP__0373 $_{-}-\mathrm{NprB}$ & pUC256E carrying NprB fused to sp $\mathrm{LP}_{\mathrm{LP}} 0373$ under $\mathrm{P}_{\mathrm{pgm}}$ control & This study \\
\hline pUC256E-sp_p_0373-pro-NprB & pUC256E carrying pro-NprB fused to $\mathrm{SP}_{\mathrm{LP} \_0373}$ under $\mathrm{P}_{\mathrm{pgm}}$ control & This study \\
\hline pUC256E-sp_p_0373-PepJ & pUC256E carrying PepJ fused to $\mathrm{sp}_{\mathrm{LP} \_0373}$ under $\mathrm{P}_{\mathrm{pgm}}$ control & This study \\
\hline pUC256E-spLP_0373-pro-PepJ & pUC256E carrying pro-PepJ fused to $\mathrm{SP}_{\mathrm{LP} \_0373}$ under $\mathrm{P}_{\text {pgm }}$ control & This study \\
\hline pUC256E-sp ${ }_{\mathrm{LP} \_0373}-\mathrm{PepA}-\mathrm{Aa}$ & pUC256E carrying PepA-Aa fused to $\mathrm{SP}_{\mathrm{LP} \_0373}$ under $\mathrm{P}_{\mathrm{pgm}}$ control & This study \\
\hline 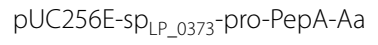 & pUC256E carrying pro-PepA-Aa fused to $\mathrm{SP}_{\mathrm{LP} \_0373}$ under $\mathrm{P}_{\text {pgm }}$ control & This study \\
\hline pUC256E-sp LP_0373-PepA-An & pUC256E carrying PepA-An fused to SP LP_0373 $_{\text {under }} P_{\text {pgm }}$ control & This study \\
\hline pUC256E-sp LP_0373 $_{\text {-pro-PepA-An }}$ & pUC256E carrying pro-PepA-An fused to $\mathrm{sp}_{\mathrm{LP} \_0373}$ under $\mathrm{P}_{\text {pgm }}$ control & This study \\
\hline 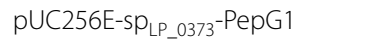 & pUC256E carrying PepG1 fused to $\mathrm{sp}_{\mathrm{LP} \_0373}$ under $\mathrm{P}_{\mathrm{pgm}}$ control & This study \\
\hline pUC256E-sp LP_0373-pro-PepG1 & pUC256E carrying pro-PepG1 fused to $\mathrm{Sp}_{\mathrm{LP} \_0373}$ under $\mathrm{P}_{\mathrm{pgm}}$ control & This study \\
\hline pUC256E-spLP_0600-PepG1 & pUC256E carrying PepG1 fused to SP $\mathrm{LP} \_0600_{\text {under }} \mathrm{P}_{\text {pgm }}$ control & This study \\
\hline pUC256E-sp sslipA $-P e p G 1$ & pUC256E carrying PepG1 fused to $\mathrm{sp}_{\text {sslipA }}$ under $\mathrm{P}_{\text {pgm }}$ control & This study \\
\hline $\mathrm{pUC256E-sp} \mathrm{M \sigma}-\mathrm{PepG} 1$ & pUC256E carrying PepG1 fused to $\mathrm{sp}_{\mathrm{M} 6}$ under $\mathrm{P}_{\mathrm{pgm}}$ control & This study \\
\hline pUC256E-sp Usp45 - PepG1 & pUC256E carrying PepG1 fused to $\mathrm{sp}_{\mathrm{Usp} 45}$ under $\mathrm{P}_{\mathrm{pgm}}$ control & This study \\
\hline pUC256E-sp LIBRARY $-P e p G 1$ & $\begin{array}{l}\text { Plasmid library of pUC256E carrying PepG1 fused to homologous signal peptide under } \\
\text { P pgm }_{\text {control }}\end{array}$ & This study \\
\hline
\end{tabular}

sequencing was performed using Illumina NextSeq500 sequencing technology at Temasek Life Sciences Laboratory (Singapore). Sequence data was quality checked, and a draft genome was obtained after assembly using SPAdes [65]. The proteome profile was established by processing the genome through DDBJ Fast Annotation and Submission Tool (https://dfast.nig.ac.jp/help_ annotation, [66]). Signal peptides and cleavage sites were predicted using the SignalP server (http://www. cbs.dtu.dk/services/SignalP/, [43]).

DNA sequences of signal peptides were amplified either from genomic DNA of target strains or through primer self-annealing using Phusion polymerase (New England BioLabs, Ipswich, USA). The PCR products were visually inspected for quality and size and then extracted from 2\% DNA agarose gels using the QIAquick PCR Purification kit (Qiagen, Hilden, Germany). Subsequently, the various DNA fragments were combined at equal concentrations. The mixture together with the linearized vector pUC256E were assembled with $20 \mathrm{bp}$ overlap using NEBuilder HiFi DNA Assembly Master Mix (New England BioLabs, Ipswich, USA). The assembled mixture was then transformed into E. coli $\mathrm{DH} 5 \alpha$ and E. coli C2925 following the manufacturer's protocol. After overnight growth, plasmids were extracted from transformed E. coli $\mathrm{C} 2925$ and E. coli DH5 $\alpha$ cells, and immediately transformed into L. plantarum and P. acidilactici, respectively.
Cells of L. plantarum were transformed as described previously [67]. In brief, cell culture was re-inoculated into MRS broth with $1 \%$ glycine at an initial $\mathrm{OD}_{600}$ of 0.25 . The cells were harvested at an $\mathrm{OD}_{600}$ of 0.5 and washed three times with an equal volume of $10 \mathrm{mM} \mathrm{MgCl}_{2}, 1 \mathrm{mM}$ $\mathrm{MgCl}_{2}$, and $30 \%(\mathrm{w} / \mathrm{v})$ PEG 1500, in sequence. The cells were then resuspended in $400 \mu \mathrm{l}$ of $30 \%$ (w/v) PEG 1500. A total of $100 \mu \mathrm{l}$ of cells was mixed with plasmids in a $1 \mathrm{~mm}$ electrode-gap cuvette which received a single pulse from a Bio-Rad Xcell Gene Pulser at $2.5 \mathrm{kV}, 25 \mu \mathrm{F}$ and $400 \Omega$. Electroporated cells were recovered in MRS broth for $2 \mathrm{~h}$ at $37^{\circ} \mathrm{C}$. To identify the positive transformants, cells were spread on MRS plates with $5 \mu \mathrm{g} / \mathrm{ml}$ erythromycin and incubated for 2 days at $37^{\circ} \mathrm{C}$.

$P$. acidilactici was transformed based on the method previously described by Rodriguez et al. [68] with some modifications. In brief, overnight grown cells were re-inoculated into MRS broth with $40 \mathrm{mM} \mathrm{DL}$ threonine at an initial $\mathrm{OD}_{600}$ of 0.25 . The cells were harvested at an $\mathrm{OD}_{600}$ of 1.3 and washed three times with an equal volume of chilled electroporation buffer (0.6 $\mathrm{M}$ sucrose, $7 \mathrm{mM}$ potassium phosphate, $1 \mathrm{mM}$ $\left.\mathrm{MgCl}_{2}, \mathrm{pH} 7.5\right)$. The cells were then incubated in prewarmed lysozyme solution $(2000 \mathrm{U} / \mathrm{ml}$ of cell suspension) for $25 \mathrm{~min}$ at $37^{\circ} \mathrm{C}$, harvested, washed three times and finally resuspended in $200 \mu$ l of electroporation buffer. Following the procedure of L. plantarum, a single pulse was added to the $P$. acidilactici and plasmid mixture with modified settings of $2.5 \mathrm{kV}, 25 \mu \mathrm{F}$ 
and $200 \Omega$. The electroporated cells were recovered and positive transformants selected as described for $L$. plantarum above.

\section{Protease activity assay}

In this study, higher secretion capacity of the tested signal peptide was defined as a higher amount of protease secreted into the media [27]. Therefore, a protease activity assay was utilized to assess the influence of the different signal peptides on protease secretion. Freshly inoculated cultures of transformed L. plantarum or $P$. acidilactici were re-inoculated into fresh media in a 96-deep well plate at an initial $\mathrm{OD}_{600}$ of 0.1 . After $24 \mathrm{~h}$, the plates were centrifuged at $3000 \times \mathrm{g}$ for $10 \mathrm{~min}$, and protease activity in the supernatant was measured according to the EnzChek ${ }^{\mathrm{TM}}$ Protease Assay Kit (Invitrogen, Carlsbad, US). The assay is based on the detection of highly fluorescent BIODIPY FL dyelabeled peptides released by protease-catalyzed hydrolysis. Protease activities in the culture were expressed in fluorescence intensity units measured with an Infinite M Nano+ plate reader (Tecan, Zurich, Switzerland) with a filter fluorometer (excitation wavelength $485 \mathrm{~nm}$, emission wavelength $530 \mathrm{~nm}$ ). During the second round of screening, protease activity for each of the analyzed secretion tags was evaluated in triplicate.

\section{Western blot analysis}

Cell pellet and culture supernatant were separated by centrifugation at $3000 \times \mathrm{g}$ for $10 \mathrm{~min}$. Proteins in the supernatant were precipitated with $100 \%(\mathrm{w} / \mathrm{v}) \mathrm{TCA}$ at a final TCA concentration of $20 \%$. The precipitate was washed with ice-cold acetone and centrifuged again at $20,000 \times \mathrm{g}$ for $10 \mathrm{~min}$. Intracellular proteins were released by lysing the cell pellets with a FastPrep homogenizer in lysis buffer $(50 \mathrm{mM}$ TrisHCl, $100 \mathrm{mM}$ $\mathrm{KCl}, \mathrm{pH}$ 7.9). Proteins precipitated from supernatants, and cell lysates were boiled with Laemmli sample buffer (Bio-Rad, Hercules, USA) and separated on 4-20\% Mini-PROTEAN $^{\circledR}$ TGX $^{\mathrm{TM}}$ Precast Protein gels using TGX running buffer (Bio-Rad, Hercules, USA). The sample gels were used for blotting as described previously [69]. Proteins were blotted onto a $0.2 \mu \mathrm{m}$ nitrocellulose membrane (Bio-Rad, Hercules, USA) through the Trans-Blot Turbo Blotting System (Bio-Rad, Hercules, USA). HRP conjugated anti- $6 \times$ His-tag antibody (ThermoFisher Scientific, Waltham, USA) and Pierce ECL Western blotting substrate (Life Technologies, Carlsbad, USA) were used to detect $6 \times$ His-tagged proteins. The blotted membrane was visualized using the ChemiDoc system (Bio-Rad, Hercules, USA).

\section{Sequence analysis of signal peptide}

The N-domain of signal peptide was defined as the peptide sequence starting from the $\mathrm{N}$-terminal methionine up to the last positively charged amino acid [49]. The net charge of the N-domain was calculated with amino acid aspartic acid (D) and glutamic acid (E) defined as -1 , lysin (K) and arginine (R) defined as +1 and all other amino acids as zero [70]. Hydrophobicity was calculated with amino acids glycine $(\mathrm{G})$, alanine $(\mathrm{A})$, valine $(\mathrm{V})$, leucine $(\mathrm{L})$, isoleucine $(\mathrm{I})$, methionine $(\mathrm{M})$, phenylalanine $(\mathrm{F})$, tryptophan $(\mathrm{W})$ and proline $(\mathrm{P})$ defined as hydrophobic and the remaining defined as hydrophilic [70]. Previous studies have shown that signal peptides adopt $\alpha$-helical conformations in interfacial environments such as cell membranes [27]. The transmembrane helix structure was predicted by a web-based transmembrane helical prediction program, TMHMM Server v. 2.0 (http:// www.cbs.dtu.dk/services/TMHMM/, [71]).

\section{Signal peptides comparison within species and genera}

To evaluate the relevance of our identified active signal peptides in other strains, all strains belonging to $L$. plantarum or $P$. acidilactici, for which complete genome sequences were available in NCBI (accessed on 10-Nov2021), were downloaded. To further evaluate the pertinence in other Lactiplantibacillus or Pediococcus species, one representative strain per species, for which a complete genome sequences was available was chosen for analysis (complete genome sequences were not always available for the type strains). L. plantarum SN13T (GenBank assembly accession: GCA_013394345.1; failed taxonomy check in NCBI) was removed from the analysis. In total, 156 strains of L. plantarum and 23 strains of $P$. acidilactici were obtained. Seven species, namely, $L$. argentoratensis, L. paraplantarum, L. pentosus, $P$. pentosaceus, $P$. claussenii, $P$. damnosus and $P$. inopinatus, contained strains, for which complete genome sequences were available from NCBI, thus these representative strains were also included in the analysis. Signal peptides were predicted for all strains using SignalP. The presence of the identified active signal peptides in all strains was assessed using an in-house python script (available from the authors upon request).

To obtain insights into signal peptide similarity at species and genus level, signal peptides were predicted for all strains mentioned above using SignalP. Strains from Secundilactobacillus malefermentans, Furfurilactobacillus rossiae, Lentilactobacillus buchneri and Levilactobacillus brevis were used as an outgroup. An in-house python script was developed, which, first identified the shared signal peptides for each pair of strains, then generated a matrix with the numbers 
of shared signal peptides for all pairs of strains, and lastly converted the matrix to a new matrix providing the percentage of shared signal peptides over the total (unique and shared) signal peptides for all pairs of strains. The similarity heatmap was generated using ClustVis (https://biit.cs.ut.ee/clustvis/, [72]).

\section{Supplementary Information}

The online version contains supplementary material available at https://doi. org/10.1186/s12864-022-08292-3.

Additional file 1: Table S1. Unique signal peptides identified from first round of screening and number of repetition in different clones.

Additional file 2: Figure S1. Full length image of western blots of L. plantarum and P. acidilactici. (A) Western blot image of L. plantarum. Lane 1-5: standard, L. plantarum wild type, L. plantarum with pUC256E, L. plantarum

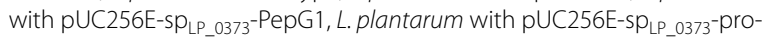
PepG1. (B) Western blot image of P. acidilactici. Lane 1-5: standard, P. acidilactici wild type, P. acidilactici with pUC256E, P. acidilactici with pUC256E-

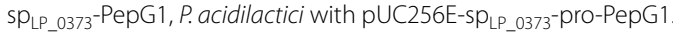

Additional file 3: Table S2. Primers used in this study. Restriction sites are in bold.

Additional file 4: Figure S2. Heatmap of signal peptide similarity comparison of L. plantarum (A) and P. acidilactici (B). GenBank assembly accession numbers are provided for each strain. Strains belonging to species other than L. plantarum and P. acidilactici are labelled with their species names and GenBank assembly accession numbers. Blue color indicates no similarity of predicted signal peptides between two strains, red color indicates $100 \%$ similarity of predicted signal peptides between two strains.

\section{Acknowledgements}

We are grateful to Shaktheeshwari Silvaraju, Ginette Ru Ying Puah and Maxim Sheludchenko (WIL@NUS Corporate Laboratory, Singapore) for extraction of genomic DNA, library preparation and whole genome sequencing of the two strains. We thank Ma Lizhou and Huang Lingling (Wilmar (Shanghai) Biotechnology Research and Development Center Co. Ltd.) for valuable discussions.

\section{Authors' contributions}

Conceived and designed the experiments: BC, OL, SK. Performed the experiments: BC, BZLL, YYC. Analyzed the data: BC. Contributed reagents/materials/ analysis tools: PS, HF. Wrote and edited the manuscript: BC, SK. All authors read, provided feedback and approved of the final version of the manuscript.

\section{Funding}

This study was funded by Wilmar International Limited (WIL@NUS Corporate Laboratory, Singapore)

\section{Availability of data and materials}

All data generated or analysed during this study are included in this published article and its supplementary information files.

\section{Declarations}

Ethics approval and consent to participate

Not applicable.

\section{Consent for publication}

Not applicable.

\section{Competing interests}

All authors are employees of Wilmar International Limited. This does not alter the authors' adherence to all BMC Genomics policies on sharing data and materials.

\section{Author details}

${ }^{1}$ Wilmar International Limited, WIL@NUS Corporate Laboratory, Centre for Translational Medicine, National University of Singapore, Singapore, Singapore. ${ }^{2}$ Wilmar International Limited, Wilmar (Shanghai) Biotechnology Research and Development Center Co. Ltd., Shanghai, China. ${ }^{3}$ Present Address: Huan Fan, Center for Integrative Conservation, Xishuangbanna Tropical Botanical Garden, Chinese Academy of Sciences, Menglun, Yunnan, People's Republic of China.

Received: 6 July 2021 Accepted: 3 January 2022

Published online: 12 January 2022

\section{References}

1. Zheng J, Wittouck S, Salvetti E, Franz CMAP, Harris HMB, Mattarelli P, et al. A taxonomic note on the genus Lactobacillus: description of 23 novel genera, emended description of the genus Lactobacillus Beijerinck 1901, and union of Lactobacillaceae and Leuconostocaceae. Int J Syst Evol Microbiol. 2020;70:2782-858.

2. Holland R, Crow V, Curry B. Lactic Acid Bacteria: Pediococcus spp. In: Fuquay JW, editor. Encyclopedia of Dairy Sciences (Second Edition). Academic Press; 2011. p. 149-152.

3. Alhaag $H$, Yuan X, Mala A, Bai J, Shao T. Fermentation characteristics of Lactobacillus plantarum and Pediococcus species isolated from sweet sorghum silage and their application as silage inoculants. Appl Sci. 2019;9(6):1247

4. Rodriguez-Palacios A, Staempfli HR, Duffield T, Weese JS. Isolation of bovine intestinal Lactobacillus plantarum and Pediococcus acidilactici with inhibitory activity against Escherichia coli 0157 and F5. J Appl Microbiol. 2009;106:393-401.

5. Vaughan EE, Heilig HGHJ, Ben-Amor K, De Vos WM. Diversity, vitality and activities of intestinal lactic acid bacteria and bifidobacteria assessed by molecular approaches. FEMS Microbiol Rev. 2005;29(3):477-90.

6. Giraffa G, Chanishvili N, Widyastuti Y. Importance of lactobacilli in food and feed biotechnology. Res Microbiol. 2010;161:480-7. https://doi.org/ 10.1016/j.resmic.2010.03.001.

7. Klaenhammer TR. Genetics of bacteriocins produced by lactic acid bacteria. FEMS Microbiol Rev. 1993;12:39-85.

8. da Silva Sabo S, Vitolo M, González JMD, de Souza Oliveira RP. Overview of Lactobacillus plantarum as a promising bacteriocin producer among lactic acid bacteria. Food Res Int. 2014;64:527-36. https://doi.org/10. 1016/j.foodres.2014.07.041.

9. LeBlanc JG, Chain F, Martín R, Bermúdez-Humarán LG, Courau S, Langella P. Beneficial effects on host energy metabolism of short-chain fatty acids and vitamins produced by commensal and probiotic bacteria. Microb Cell Factories. 2017;16:1-10.

10. Costabile A, Buttarazzi I, Kolida S, Quercia S, Baldini J, Swann JR, et al. An in vivo assessment of the cholesterol-lowering efficacy of Lactobacillus plantarum ECGC 13110402 in normal to mildly hypercholesterolaemic adults. PLoS One. 2017;12:e0187964. https://doi.org/10.1371/journal. pone.0187964.

11. Li S, Zhao Y, Zhang L, Zhang X, Huang L, Li D, et al. Antioxidant activity of Lactobacillus plantarum strains isolated from traditional Chinese fermented foods. Food Chem. 2012;135:1914-9.

12. Ezendam J, Van Loveren H. Probiotics: immunomodulation and evaluation of safety and efficacy. Nutr Rev. 2006;64:1-14.

13. Markowiak P, Ślizewska K. Effects of probiotics, prebiotics, and synbiotics on human health. Nutrients. 2017;9(9):1021.

14. Behera SS, Ray RC, Zdolec N. Lactobacillus plantarum with functional properties: an approach to increase safety and shelf-life of fermented foods. Biomed Res Int. 2018:2018:9361614.

15. Cui S, Zhao N, Lu W, Zhao F, Zheng S, Wang W, et al. Effect of different Lactobacillus species on volatile and nonvolatile flavor compounds in juices fermentation. Food Sci Nutr. 2019;7:2214-23.

16. Lim YH, Foo HL, Loh TC, Mohamad R, Abdullah N. Comparative studies of versatile extracellular proteolytic activities of lactic acid bacteria and their potential for extracellular amino acid productions as feed supplements. J Anim Sci Biotechnol. 2019;10:1-13.

17. Broadbent JR, Cai H, Larsen RL, Hughes JE, Welker DL, De Carvalho $V G$, et al. Genetic diversity in proteolytic enzymes and amino acid 
metabolism among Lactobacillus helveticus strains. J Dairy Sci. 2011;94:4313-28.

18. Sadat-Mekmene L, Genay M, Atlan D, Lortal S, Gagnaire V. Original features of cell-envelope proteinases of Lactobacillus helveticus. A review. Int J Food Microbiol. 2011;146:1-13.

19. Stefanitsi D, Sakellaris G, Garel J, renaud. The presence of two proteinases associated with the cell wall of Lactobacillus bulgaricus. FEMS Microbiol Lett. 1995;128:53-8.

20. Simbaya J, Slominski BA, Guenter W, Morgan A, Campbell LD. The effects of protease and carbohydrase supplementation on the nutritive value of canola meal for poultry: in vitro and in vivo studies. Anim Feed Sci Technol. 1996;61:219-34.

21. Rooke JA, Slessor M, Fraser H, Thomson JR. Growth performance and gut function of piglets weaned at four weeks of age and fed protease-treated soya-bean meal. Anim Feed Sci Technol. 1998;70:175-90.

22. Borrero J, Jiménez JJ, Gútiez L, Herranz C, Cintas LM, Hernández PE. Protein expression vector and secretion signal peptide optimization to drive the production, secretion, and functional expression of the bacteriocin enterocin A in lactic acid bacteria. J Biotechnol. 2011;156:76-86.

23. Freudl R. Signal peptides for recombinant protein secretion in bacterial expression systems. Microb Cell Factories. 2018;17:1-10.

24. Brockmeier $U$, Wendorff $M$, Eggert T. Versatile expression and secretion vectors for Bacillus subtilis. Curr Microbiol. 2006;52:143-8.

25. Piard JC, Hautefort I, Fischetti VA, Ehrlich SD, Fons M, Gruss A. Cell wall anchoring of the Streptococcus pyogenes M6 protein in various lactic acid bacteria. J Bacteriol. 1997;179:3068 LP-3072. https://doi.org/10.1128/jb. 179.9.3068-3072.1997.

26. Borrero J, Jiménez JJ, Gútiez L, Herranz C, Cintas LM, Hernández PE. Use of the usp45 lactococcal secretion signal sequence to drive the secretion and functional expression of enterococcal bacteriocins in Lactococcus lactis. Appl Microbiol Biotechnol. 2011;89:131-43. https://doi.org/10. 1007/s00253-010-2849-z.

27. Mathiesen G, Sveen A, Brurberg MB, Fredriksen L, Axelsson L, Eijsink VGH. Genome-wide analysis of signal peptide functionality in Lactobacillus plantarum WCFS1. BMC Genomics. 2009:10:425.

28. Mathiesen G, Sveen A, Piard JC, Axelsson L, Eijsink VGH. Heterologous protein secretion by Lactobacillus plantarum using homologous signal peptides. J Appl Microbiol. 2008:105:215-26.

29. Jensen K, Østergaard PR, Wilting R, Lassen SF. Identification and characterization of a bacterial glutamic peptidase. BMC Biochem. 2010;11:47.

30. Pérez-Arellano I, Zúñiga M, Pérez-Martínez G. Construction of compatible wide-host-range shuttle vectors for lactic acid bacteria, and Escherichia coli. Plasmid. 2001;46:106-16.

31. Shareck J, Choi Y, Lee B, Miguez CB. Cloning vectors based on cryptic plasmids isolated from lactic acid bacteria: their characteristics and potential applications in biotechnology; 2004.

32. Duong T, Miller MJ, Barrangou R, Azcarate-Peril MA, Klaenhammer TR. Construction of vectors for inducible and constitutive gene expression in Lactobacillus. Microb Biotechnol. 2011:4:357-67.

33. Sørvig E, Mathiesen G, Naterstad K, Eijsink VGH, Axelsson L. Highlevel, inducible gene expression in Lactobacillus sakei and Lactobacillus plantarum using versatile expression vectors. Microbiology. 2005:151:2439-49.

34. Leenhouts KJ, Tolner B, Bron S, Kok J, Venema G, Seegers JF. Nucleotide sequence and characterization of the broad-host-range lactococcal plasmid pWVO1. Plasmid. 1991;26:55-66

35. Scheirlinck T, Ankmichiels F, Stanssens P. Characterization of a grampositive broad-host-range; 1989. p. 20.

36. Sørvig E, Skaugen M, Naterstad K, Eijsink VGH, Axelsson L. Plasmid p256 from Lactobacillus plantarum represents a new type of replicon in lactic acid bacteria, and contains a toxin-antitoxin-like plasmid maintenance system. Microbiology. 2005;151:421-31.

37. Tran L, Wu XC, Wong SL. Cloning and expression of a novel protease gene encoding an extracellular neutral protease from Bacillus subtilis. J Bacteriol. 1991;173:6364-72.

38. Emri T, Szilágyi M, László K, M-hamvas M, Pócsi I. PepJ is a new extracellular proteinase of Aspergillus nidulans. Folia Microbiol (Praha). 2009:54:105-9.

39. Berka RM, Ward M, Wilson LJ, Hayenga KJ, Kedama KH, Carlomagno LP, et al. Molecular cloning and deletion of the gene encoding aspergillopepsin A from Aspergillus awamori. Gene. 1990;86:153-62.
40. Jarai G, Buxton F. Nitrogen, carbon, and pH regulation of extracellular acidic proteases of Aspergillus niger. Curr Genet. 1994;400:238-44.

41. Lim PY, Tan LL, Ow DS-W, Wong FT. A propeptide toolbox for secretion optimization of Flavobacterium meningosepticum endopeptidase in Lactococcus lactis. Microb Cell Factories. 2017;16:221. https://doi.org/10. 1186/s12934-017-0836-0.

42. Hazebrouck S, Pothelune L, Azevedo V, Corthier G, Wal JM, Langella P. Efficient production and secretion of bovine $\beta$-lactoglobulin by Lactobacillus casei. Microb Cell Factories. 2007:6:1-8.

43. Almagro Armenteros JJ, Tsirigos KD, Sønderby CK, Petersen TN, Winther $\mathrm{O}$, Brunak S, et al. SignalP 5.0 improves signal peptide predictions using deep neural networks. Nat Biotechnol. 2019;37:420-3. https://doi.org/10. 1038/s41587-019-0036-z.

44. Antelmann $\mathrm{H}$, Tjalsma $\mathrm{H}$, Voigt B, Ohlmeier S, Bron S, Van DJM, et al. A proteomic view on genome-based signal peptide predictions the extracellular proteome of. Genome Res. 2001;11:1484-502.

45. Nielsen $\mathrm{H}$, Engelbrecht J. Identification of prokaryotic and eukaryotic signal peptides and prediction of their cleavage sites artificial neural networks have been used for many biological. Protein Eng. 1997;10:1-6.

46. Auclair SM, Bhanu MK, Kendall DA. Signal peptidase I: cleaving the way to mature proteins. Protein Sci. 2012;21:13-25.

47. Rodic A, Blagojevic B, Zdobnov E, Djordjevic M, Djordjevic M. Understanding key features of bacterial restriction-modification systems through quantitative modeling. BMC Syst Biol. 2017;11(Suppl 1):1-15.

48. Vasu K, Nagaraja V. Diverse functions of restriction-modification systems in addition to cellular defense. Microbiol Mol Biol Rev. 2013;77:53-72.

49. Fu G, Liu J, Li J, Zhu B, Zhang D. Systematic screening of optimal signal peptides for secretory production of heterologous proteins in Bacillus subtilis. J Agric Food Chem. 2018;66:13141-51. https://doi.org/10.1021/ acs.jafc.8b04183.

50. Peng C, Shi C, Cao X, LiY, Liu F, Lu F. Factors influencing recombinant protein secretion efficiency in gram-positive bacteria: signal peptide and beyond. Front Bioeng Biotechnol. 2019;7:1-9.

51. Karlskås IL, Maudal K, Axelsson L, Rud I, Eijsink VGH, Mathiesen G. Heterologous protein secretion in lactobacilli with modified pSIP vectors. PLoS One. 2014;9:1-9.

52. Lin J, Zou Y, Ma C, Liang Y, Ge X, Chen Z, et al. Construction and characterization of three protein-targeting expression system in Lactobacillus casei. FEMS Microbiol Lett. 2016;363. https://doi.org/10.1093/femsle/ fnw041.

53. Subramaniam M, Baradaran A, Rosli MI, Rosfarizan M, Khatijah Y, Raha AR. Effect of signal peptides on the secretion of $\beta$-cyclodextrin glucanotransferase in Lactococcus lactis NZ9000. J Mol Microbiol Biotechnol. 2012;22:361-72. https://doi.org/10.1159/000343921.

54. Kaur T, Balgir PP, Kaur B. Construction of a shuttle expression vector for lactic acid bacteria. J Genet Eng Biotechnol. 2019;17:10.

55. Kiewiet R, Kok J, Seegers JFML, Venema G, Bron S. The mode of replication is a major factor in segregational plasmid instability in Lactococcus lactis. Appl Environ Microbiol. 1993;59:358-64.

56. Tokmakov AA, Kurotani A, Takagi T, Toyama M, Shirouzu M, Fukami Y, et al. Multiple post-translational modifications affect heterologous protein synthesis. J Biol Chem. 2012;287:27106-16. https://doi.org/10.1074/jbc. M112.366351.

57. Ng DTW, Sarkar CA. Engineering signal peptides for enhanced protein secretion from Lactococcus lactis. Appl Environ Microbiol. 2013;79:347-56.

58. Ravn P, Arnau J, Madsen SM, Vrang A, Israelsen H. Optimization of signal peptide SP310 for heterologous protein production in Lactococcus lactis. Microbiology. 2003;149:2193-201. https://doi.org/10.1099/mic.0.26299-0.

59. Caspers M, Brockmeier U, Degering C, Eggert T, Freudl R. Improvement of Sec-dependent secretion of a heterologous model protein in Bacillus subtilis by saturation mutagenesis of the $\mathrm{N}$-domain of the AmyE signal peptide. Appl Microbiol Biotechnol. 2010;86:1877-85. https://doi.org/10. 1007/s00253-009-2405-X

60. Castiñeiras TS, Williams SG, Hitchcock A, Cole JA, Smith DC, Overton TW. Development of a generic $\beta$-lactamase screening system for improved signal peptides for periplasmic targeting of recombinant proteins in Escherichia coli; 2018. p. 1-18.

61. Heggeset TMB, Kucharova V, Naerdal I, Valla S, Sletta H, Ellingsen TE, et al. Combinatorial mutagenesis and selection of improved signal sequences and their application for high-level production of translocated 
heterologous proteins in Escherichia coli. Appl Environ Microbiol. 2013;79:559-68.

62. Brockmeier U, Caspers M, Freudl R, Jockwer A, Noll T, Eggert T. Systematic screening of all signal peptides from Bacillus subtilis: a powerful strategy in optimizing heterologous protein secretion in gram-positive bacteria. J Mol Biol. 2006;362:393-402.

63. Le Loir Y, Nouaille S, Commissaire J, Brétigny L, Langella P. Signal peptide and propeptide optimization for heterologous protein secretion in Lactococcus lactis. Appl Environ Microbiol. 2001;67:4119-27. https://doi.org/ 10.1128/AEM.67.9.4119.

64. Sørvig E, Grönqvist S, Naterstad K, Mathiesen G, Eijsink VGH, Axelsson L. Construction of vectors for inducible gene expression in Lactobacillus sakei and L. plantarum. FEMS Microbiol Lett. 2003;229:119-26.

65. Bankevich A, Nurk S, Antipov D, Gurevich AA, Dvorkin M, Kulikov AS, et al. SPAdes: a new genome assembly algorithm and its applications to single-cell sequencing. J Comput Biol. 2012;19:455-77. https://doi.org/10, 1089/cmb.2012.0021.

66. Tanizawa Y, Fujisawa T, Kaminuma E, Nakamura Y, Arita M. DFAST and DAGA: web-based integrated genome annotation tools and resources. Biosci Microbiota Food Health. 2016:35:173-84.

67. Aukrust T, Blom H. Transformation of Lactobacillus strains used in meat and vegetable fermentations. Food Res Int. 1992;25:253-61.

68. Rodríguez MC, Alegre MT, Mesas JM. Optimization of technical conditions for the transformation of Pediococcus acidilactici P60 by electroporation. Plasmid. 2007;58:44-50. https://doi.org/10.1016/JPLASMID.2006.12.005.

69. Chen B, Ling H, Chang MW. Transporter engineering for improved tolerance against alkane biofuels in Saccharomyces cerevisiae. Biotechnol Biofuels. 2013;6:21. https://doi.org/10.1186/1754-6834-6-21.

70. Degering C, Eggert T, Puls M, Bongaerts J, Evers S, Maurer KH, et al. Optimization of protease secretion in bacillus subtilis and bacillus licheniformis by screening of homologousand heterologous signal peptides. Appl Environ Microbiol. 2010;76:6370-6.

71. Krogh A, Larsson B, von Heijne G, Sonnhammer ELL. Predicting transmembrane protein topology with a hidden markov model: application to complete genomes11Edited by F. Cohen. J Mol Biol. 2001;305:567-80 https://doi.org/10.1006/jmbi.2000.4315.

72. Metsalu T, Vilo J. ClustVis: a web tool for visualizing clustering of multivariate data using principal component analysis and heatmap. Nucleic Acids Res. 2015;43:W566-70. https://doi.org/10.1093/nar/gkv468.

\section{Publisher's Note}

Springer Nature remains neutral with regard to jurisdictional claims in published maps and institutional affiliations.

Ready to submit your research? Choose BMC and benefit from:

- fast, convenient online submission

- thorough peer review by experienced researchers in your field

- rapid publication on acceptance

- support for research data, including large and complex data types

- gold Open Access which fosters wider collaboration and increased citations

- maximum visibility for your research: over $100 \mathrm{M}$ website views per year

At BMC, research is always in progress.

Learn more biomedcentral.com/submissions 